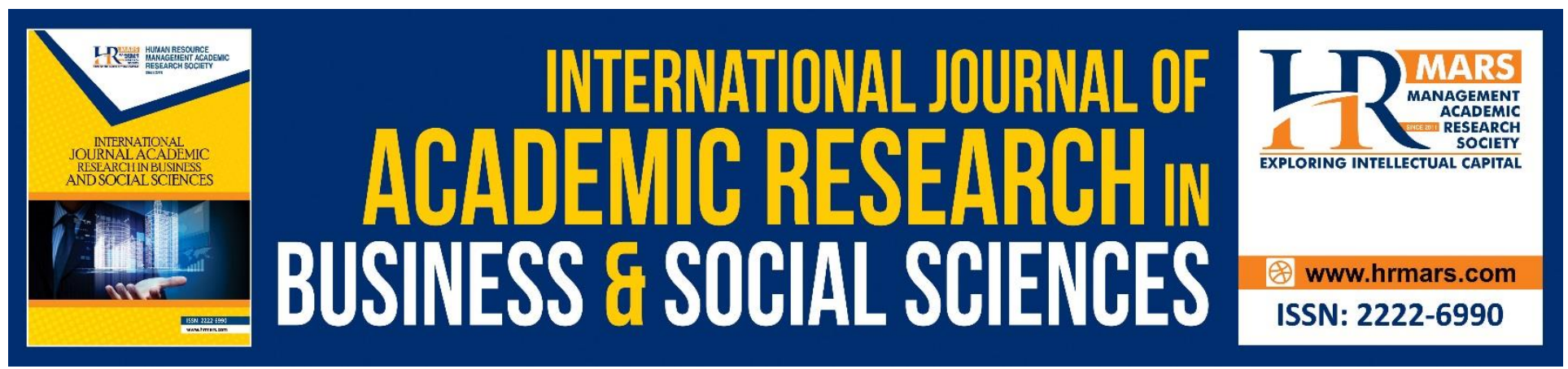

\title{
The Assessment of Patient's Satisfaction and Opinions of their Experience during Admission in the Tertiary Care Hospital
}

Bushra Maroof, Syeda Sidra Tasneem, Rubina Jabeen, Rabia Taskeen

To Link this Article: http://dx.doi.org/10.6007/IJARBSS/v9-i5/5905

DOI: 10.6007/IJARBSS/v9-i5/5905

Received: 11 March 2019, Revised: 08 April 2019, Accepted: 21 April 2019

Published Online: 29 May 2019

In-Text Citation: (Maroof, Tasneem, Jabeen, \& Taskeen, 2019)

To Cite this Article: Maroof, B., Tasneem, S. S., Jabeen, R. J., \& Taskeen, R. (2019). The Assessment of Patient's Satisfaction and Opinions of their Experience during Admission in the Tertiary Care Hospital. International Journal of Academic Research Business and Social Sciences, 9(5), 555-577.

Copyright: (C) 2019 The Author(s)

Published by Human Resource Management Academic Research Society (www.hrmars.com)

This article is published under the Creative Commons Attribution (CC BY 4.0) license. Anyone may reproduce, distribute, translate and create derivative works of this article (for both commercial and non-commercial purposes), subject to full attribution to the original publication and authors. The full terms of this license may be seen

at: http://creativecommons.org/licences/by/4.0/legalcode

Vol. 9, No. 5, 2019, Pg. 555 - 577

http://hrmars.com/index.php/pages/detail/IJARBSS

JOURNAL HOMEPAGE

Full Terms \& Conditions of access and use can be found at http://hrmars.com/index.php/pages/detail/publication-ethics 


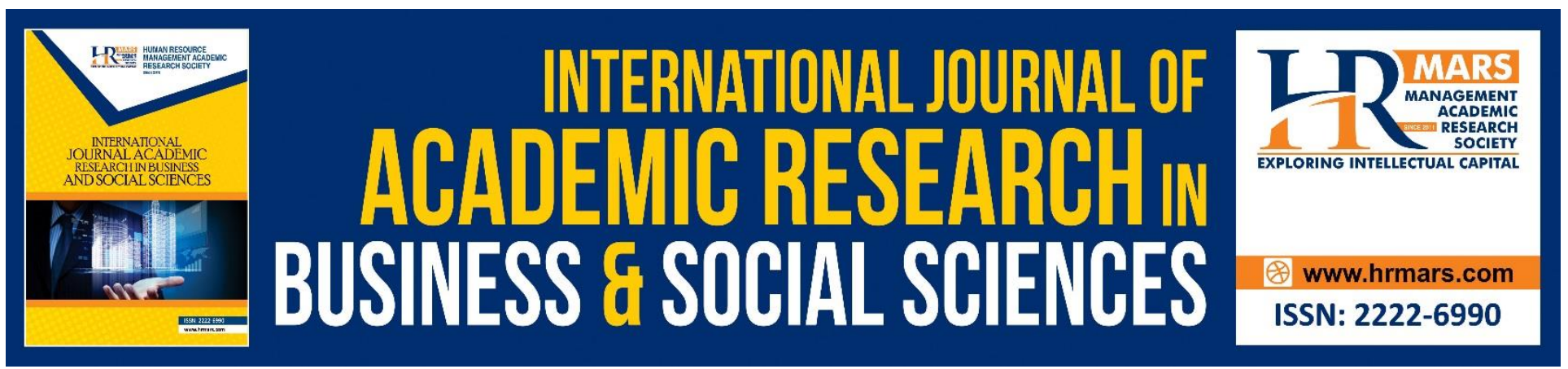

\title{
The Assessment of Patient's Satisfaction and Opinions of their Experience during Admission in the Tertiary Care Hospital
}

\author{
Bushra Maroof ${ }^{1}$, Syeda Sidra Tasneem², Rubina Jabeen ${ }^{3}$, Rabia \\ Taskeen 4 \\ ${ }^{1}$ Post RN, ${ }^{2}$ Director, ${ }^{3}$ Principal, ${ }^{3}$ Lecturer, Nursing College, The Superior College Lahore \\ 1Email: ali.90waqas@gmail.com
}

\section{Abstract}

Pakistan is undergone of high pressure on health care system a patient has to face a lot of problems because of this growing pressure. Patient become more conscious and demanding their concerns related to their health have reached to the top these concerns put more pressure on the health system, hospitals and indirectly on patients. Patient satisfaction is one of the main components of patient wellbeing as well said if our mind is satisfied than half of the body will also be satisfied. So, we can say patient satisfaction is an important factor that leads to the patient wellbeing. Patient first experience at the time of admission laid the foundation of his or her satisfaction further ahead. As Pakistan is a developing country tertiary hospital are in dire need of growth and development patient experience at the time of admission is not satisfactory, so their opinions are also not up to the mark. No doubt tertiary hospitals are on the journey of progress but still concerns are requiring building patient satisfaction and positive opinions. Respected by the students as well as society. Aim: to discuss the patient level of satisfaction and their opinions about admission in a tertiary care hospital. Design: A co relational qualitative study was adopted to illustrate mention variable. Method: Different patients were asked about their opinions through a self-administered well-structured questionnaire .sample size was determined through a formula. According to that formula sample size was 110 that was analyzed by SPSS version 16. Result: Result shows that mostly patients have negative opinion regarding hospital admission in tertiary care hospital that is the reflection of their experience of admission stress should be given to the appropriate policies so that the patient satisfaction can be increase by upgrading the hospital admission process according to the patients' needs and demand accordingly.

Introduction

Satisfaction from anyone is important as it is an important feedback and outcome. Patient satisfaction is central in all health care systems as always first glance leaves everlasting impression patients 
admission in a tertiary care hospital same as form the bases of their experiences that develop next in form of their perceptions regarding admissions in tertiary care hospitals. Patient satisfaction on admission is defined as "inpatients personal evaluation of health care services and providers while on admission, it is about the way the patient is treated and the facilities offered to him while on admission in a hospital" As now the public have become more conscious regarding the provision of services which are being provided to them (Delbanco, 1996) their awareness regarding health care system is much more evident .

There are some factors that determine the patient satisfaction at the time of admission these, (1) doctor nurses' attitudes (2) food (3) sanitation (4) Quality of services (5) Medication services.

But now the health policy makers are more concerned regarding patient views of their experiences of stay in hospital as well as the sufferings at the time of admission Thus, they are more conscious in making the strategies that utilize the services in effective manner. As continue quality improvement id directly linked to the patient satisfaction.

Every researcher has its own idea and views regarding patient experience of hospital admission in a tertiary care hospital. In Pakistan studies have only discuss the specific areas e: g emergency departments (Qidwai , 2005) day care surgeries Ahmed et al ,(2005) but our study focused mainly on assessing patient satisfaction and opinions on experience about admission in tertiary care hospital Pakistan.

Study will help in identifying the areas that cause least satisfaction I the patient at the time of admission. So that an effective change can be brought out in the continue health services for the improvement of satisfaction in the patient at the time of admission or overall stay in hospital, as in one study the most highly dissatisfied areas in the Pakistan were the financial aspects .Pakistan is a developing countries technology is not much advance as require, overcrowding, lack of survives, less number of health care providers is also an issue these are the things that cause dissatisfaction.

\section{Objective}

1. To assess the patient satisfaction and their opinions at the time of admission in tertiary hospitals of Pakistan.

2. To assess the patient opinion regarding admission in a tertiary care hospital of Pakistan.

\section{Problem Statement}

Patient knowledge and expectation from the health care services had totally been changed now they become more demanding regarding their health services, their provision and sustainability ,their views have been changed they want attention, approach, accessibility, and resources as well as proper communication channels .patient satisfaction at the time of admission in a tertiary care hospital is a main indicator that determine all theses, and the basic responsibility of any health care setting is also a patient satisfaction. Modification and change in health care strategies and policies now have been become more evident to achieve all these satisfactions but the need is to know which things are require bringing all these satisfaction and positive opinions of the patients at least about at the time of admission that directly or indirectly increase all these. In Pakistan as there is a major problem of overcrowding, poor number of health care providers as compare to patient ratio, poor 
INTERNATIONAL JOURNAL OF ACADEMIC RESEARCH IN BUSINESS AND SOCIAL SCIENCES

Vol. 9, No. 5, May, 2019, E-ISSN: 2222-6990 ㄷ 2019 HRMARS

hygienic conditions, slow technological advancement keeping in mind all these it's become very important to achieve and maintain patient satisfaction

\section{Significance}

Present study in patient satisfaction and opinions of their experience at the time of admission in tertiary care hospitals in Pakistan will give knowledge and understanding regarding this aspect and we will be able to know the areas of satisfaction as well as dissatisfaction. The study will also help in modifying the policies accordingly. The present study will also provide a help for the future research. Basically, this study is a different paradigm as patient satisfaction is a basic component and focus of any health care system as public become more aware regarding their health and demanding for their health care services provision. Moreover, Patient satisfaction id require for their well beings, present study will improve understanding regarding all these factors that cause satisfaction and dissatisfaction, determinants that determine their opinions and policies that will help in the improvement of patient satisfaction. It will also provide learning areas for the future studies it will also provide deep sense of these variables that further support patient satisfaction.

\section{Literature Review}

In this section we will review the literatures on patient satisfaction and opinions of their experience on their admission in tertiary care hospitals in Pakistan. Only few studies have been conducted in the Pakistan on the patient satisfaction, but the main focus was emergency care or department this will study will cover another area of patient satisfaction that is related to the hospital admission the study results will help in the administration of the hospital as well as hospital management.

\section{Patient Satisfaction}

Patient satisfaction is a global concern and the focus of health care system as well. The first research was started on this burning issue on 1970s and early 1980s. Patient satisfaction combine two things patient needs and patient expectations as well as the level of quality of care that is being provided to the patient level either it can achieve the patient expectations level or not. Patient satisfaction also linked to the compliance with medical treatment. It can be justifying by saying this phenomenon contains both medical as well as non-medical issues. Patient satisfaction is a key indicator that determines the quality of care that being provided at the time of admission (Singh, 1989). patient satisfaction is not only influenced by the clinical factors but there are also many other non-clinical factors too that influence patient satisfaction (Agrawal, 2006). Patient satisfaction also act as a tool for the measurement of quality of care that is being provided Alam (2008). Clinical factors are availability of medicines, doctors and nurses behaviors, cost of resources, hospital management, patient privacy, physical ease, emotional support as well as respect (Jenkinson, et al , 2002). as public become more active need assessment is the need of hour in order to prevent any type of mismatch between patient expectations and the services which are being provided that can be a cause of dissatisfaction thus, it is necessary to understand the patient views, needs, feelings and perspectives. Patient feedback must be accepted and respected to bring changes in the sustaining policies accordingly. So, that their satisfaction level can be assessed, and modification brings accordingly Boyer et al, 2006. 
Pakistan is a country with the people of low income population is growing much faster as compared to the development of country literacy rate is also an issue which is higher in the urban areas as compared to the rural areas which also helps a lot in developing patient experiences regarding their admission in the hospitals Pakistan Economy Survey, 2011.

When services match patient expectations that help in the development of patient satisfaction when services fall patient become dissatisfied. Patient satisfaction decide the future of health care providers and health care system that periodically measured by the health policy makers (Pasuraman, et al., 1985).

\section{Patient Experience on Admission}

Patients experience help as a tool in developing future actions plans (Wensing, et al, 2003). Pakistan is a developing country and as like other developing countries it's also need improvement in the health care system. Provision must be compatible with the patient wishes and needs in accordance to their satisfaction. As different patient has different perceptions they also have different views regarding their care of health care organizations and also regarding for the health care providers either they are nurse or doctors. Patient came in emergency and outpatient departments with different problems ranging from minor ailment to highly fetal diseases they must be treated according as normally said first impression always last long perceptions overcrowded emergencies irritated health care providers effect a lot on the patient experiences because they are suffering pains that time. Overcrowding prevalently and adversely effects patient experiences on admission.

\section{Methodology}

\section{Research Methodology}

This study is conducted to assess the patient satisfaction and opinions of experience on admission in tertiary care hospitals a descriptive cross-sectional research design will be used for the study to assess patient satisfaction and opinions on experience on admission in a tertiary care hospital in Pakistan

\section{Total population and size}

The research design based on descriptive and cross-sectional study. The population of the study was 200 patient of Jinnah hospital Lahore. The total sample size of 200 patients was selected randomly from total population.

\section{Research Instrument}

This is a descriptive study as self-administer and modified version of questionnaire of the article "Patient satisfaction and opinions of their experience during admission in a tertiary care hospitals in Pakistan -Cross sectional study" consisted of two sections section (A) contain demographic data section (B) contain questions section $B$ composed of five scale likert scale that elicited response from the participants with response options strongly disagree (SD) Disagree(D) neutral(N) agree (A) strongly agree(SA). 
INTERNATIONAL JOURNAL OF ACADEMIC RESEARCH IN BUSINESS AND SOCIAL SCIENCES

Vol. 9, No. 5, May, 2019, E-ISSN: 2222-6990 (C) 2019 HRMARS

\section{Setting Of study}

Setting of the study will be the patient of the Jinnah Hospital Lahore. The participant will be belonging to the different socioeconomically status and different demographic be ground the participant will be male and female.

\section{Sample size and Sampling technique}

Data will be collected from the participants' through self-administered questionnaire and the participant selected through simple random sampling, sample size foe the study was 200 which was calculated from Slovin \s formula of calculation which is mentioned here.

Total Number of the Participants

If $\mathrm{N}$ =population $\mathrm{n}=$ Sample size $\quad \mathrm{E}=$ Margin of error

$$
\begin{aligned}
& n=N / 1=+(N)(E) \\
& n=150 / 1+(150)(150) \\
& n=151 / 1.375 \\
& n=110
\end{aligned}
$$

\section{Method of Data Collection}

Data was collected through survey and the questionnaire was floated by the researcher herself. The 120 copies of questionnaire were circulated to the students and recovered on the spot.

\section{Data Analysis}

Inferential statistics of Chi-square(X2) were used to analyses the association between the variable. Reliability assessed using Cranach's Alpha AND ITS VALUE OF 0.65 was demonstrated that the questionnaire was reliable. Regression amylases were carried out to determine whether there was the linear trend between the variable. And sensitivity analyses were used to examine the result. In the end, all the data were put into the software SPSS21 version and the finding and result were drawn on the basis of statistical procedure.

\section{Results}

Table 1

Gender

\begin{tabular}{|ll|l|l|l|l|}
\hline & & Frequency & Percent & Valid Percent & $\begin{array}{l}\text { Cumulative } \\
\text { Percent }\end{array}$ \\
\hline \multirow{4}{*}{ Valid } & MALE & 61 & 55.5 & 55.5 & 55.5 \\
& FEMALE & 49 & 44.5 & 44.5 & 100.0 \\
& Total & 110 & 100.0 & 100.0 & \\
\hline
\end{tabular}

Interpretations:

Table1: shows that the respondents of the study are $55.45 \%$ male and 44.555 female 
INTERNATIONAL JOURNAL OF ACADEMIC RESEARCH IN BUSINESS AND SOCIAL SCIENCES Vol. 9, No. 5, May, 2019, E-ISSN: 2222-6990 @ 2019 HRMARS

Table 2

Marital status

\begin{tabular}{|ll|l|l|l|l|}
\hline & Frequency & Percent & Valid Percent & $\begin{array}{l}\text { Cumulative } \\
\text { Percent }\end{array}$ \\
\hline \multirow{4}{*}{ Valid } & Married & 69 & 62.7 & 62.7 & 62.7 \\
& Single & 40 & 36.4 & 36.4 & 99.1 \\
& 3 & 1 & .9 & .9 & 100.0 \\
& Total & 110 & 100.0 & 100.0 & \\
\hline
\end{tabular}

Table: 2 shows that the marital status of the respondents of the study married respondents are $62.73 \%$ and unmarried $36.36 \%$

Table 3

Age group

\begin{tabular}{|ll|l|l|l|l|}
\hline & Frequency & Percent & Valid Percent & $\begin{array}{l}\text { Cumulative } \\
\text { Percent }\end{array}$ \\
\hline \multirow{4}{*}{ Valid } & 18-25years & 39 & 35.5 & 35.5 & 35.5 \\
& 25-35years & 37 & 33.6 & 33.6 & 69.1 \\
& 35-50years & 22 & 20.0 & 20.0 & 89.1 \\
& above50 years & 12 & 10.9 & 10.9 & 100.0 \\
Total & 110 & 100.0 & 100.0 & \\
\hline
\end{tabular}

Table: 3 shows that the respondents of the study belong to the different age group those who belong to the age of $18-25$ are $35.45 \%$ those who belong to $25-35$ year of age are $33.64 \%$ those who are $35-50$ year of age are $20 \%$ those who belong to above 50 are 10.915 .

\section{Table 4}

Qualification

\begin{tabular}{|ll|l|l|l|l|}
\hline & Frequency & Percent & Valid Percent & $\begin{array}{l}\text { Cumulative } \\
\text { Percent }\end{array}$ \\
\hline \multirow{4}{*}{ Valid } & illiterate & 31 & 28.2 & 28.2 & 28.2 \\
& primary & 12 & 10.9 & 10.9 & 39.1 \\
& matric & 29 & 26.4 & 26.4 & 65.5 \\
& Other & 38 & 34.5 & 34.5 & 100.0 \\
& Total & 110 & 100.0 & 100.0 & \\
\hline
\end{tabular}

Table 4 : shows different qualification level of the respondents illiterate are $28.18 \%$ primary passed are $10.91 \%$ metric passed $26.36 \%$ and other $34.55 \%$. 
INTERNATIONAL JOURNAL OF ACADEMIC RESEARCH IN BUSINESS AND SOCIAL SCIENCES Vol. 9, No. 5, May, 2019, E-ISSN: 2222-6990 @ 2019 HRMARS

Not given enough information about condition and treatment

\begin{tabular}{|cl|l|l|l|l|}
\hline & Frequency & Percent & Valid Percent & $\begin{array}{l}\text { Cumulative } \\
\text { Percent }\end{array}$ \\
\hline \multirow{4}{*}{ Valid } & Strongly disagree & 14 & 12.7 & 12.7 & 12.7 \\
& Disagree & 3 & 2.7 & 2.7 & 15.5 \\
& Neutral & 4 & 3.6 & 3.6 & 19.1 \\
& Agree & 88 & 80.0 & 80.0 & 99.1 \\
& strongly agree & 1 & .9 & .9 & 100.0 \\
Total & 110 & 100.0 & 100.0 & \\
\hline
\end{tabular}

Table 5: shows Percentage Table shows of respondents who are strongly disagree with that not given enough information about condition and treatment are $12.73 \%$ disagree are $2.727 \%$ those are neutral $3.636 \%$ and those $60 \%$ and strongly disagree 0.000

Table 6:

Not given enough privacy during treatment and examination

\begin{tabular}{|c|l|l|l|l|l|}
\hline & Frequency & Percent & Valid Percent & $\begin{array}{l}\text { Cumulative } \\
\text { Percent }\end{array}$ \\
\hline \multirow{4}{*}{ Vtrongly disagree } & 9 & 8.2 & 8.2 & 8.2 \\
Disagree & 7 & 6.4 & 6.4 & 14.5 \\
& Neutral & 4 & 3.6 & 3.6 & 18.2 \\
& Agree & 89 & 80.9 & 80.9 & 99.1 \\
Strongly agree & 1 & .9 & .9 & 100.0 \\
Total & 110 & 100.0 & 100.0 & \\
\hline
\end{tabular}

Table 6: shows percentage of respondent who are strongly disagree are $8.182 \%$ disagree are $6.354 \%$ neutral $3.636 \%$ agree $80.91 \%$ strongly agree are $0.000 \%$.

tot given enough privacy during treatment and examination

\begin{tabular}{|c|l|l|l|l|l|}
\hline & Frequency & Percent & Valid Percent & $\begin{array}{l}\text { Cumulative } \\
\text { Percent }\end{array}$ \\
\hline \multirow{6}{*}{ Valid } & Strongly disagree & 9 & 8.2 & 8.2 & 8.2 \\
& Disagree & 7 & 6.4 & 6.4 & 14.5 \\
& Neutral & 4 & 3.6 & 3.6 & 18.2 \\
& Agree & 89 & 80.9 & 80.9 & 99.1 \\
strongly agree & 1 & .9 & .9 & 100.0 \\
Total & 110 & 100.0 & 100.0 & \\
\hline
\end{tabular}


INTERNATIONAL JOURNAL OF ACADEMIC RESEARCH IN BUSINESS AND SOCIAL SCIENCES

Vol. 9, No. 5, May, 2019, E-ISSN: 2222-6990 (C) 2019 HRMARS

Table shows percentage of the respondents that are strongly disagree in the regard of not given enough privacy during treatment and examination are $8.182 \%$ disagree are $6.364 \%$ neutral are $3.636 \%$ agree are $80.91 \%$ and strongly agree are $0.000 \%$

\section{Table 8}

Had to wait a long time before getting a bed in the ward

\begin{tabular}{|c|c|c|c|c|c|}
\hline & & Frequency & Percent & Valid Percent & $\begin{array}{l}\text { Cumulative } \\
\text { Percent }\end{array}$ \\
\hline \multirow{6}{*}{ Valid } & Strongly disagree & 9 & 8.2 & 8.2 & 8.2 \\
\hline & Disagree & 4 & 3.6 & 3.6 & 11.8 \\
\hline & Neutral & 22 & 20.0 & 20.0 & 31.8 \\
\hline & Agree & 73 & 66.4 & 66.4 & 98.2 \\
\hline & strongly agree & 2 & 1.8 & 1.8 & 100.0 \\
\hline & Total & 110 & 100.0 & 100.0 & \\
\hline
\end{tabular}

Table 8: shows the percentage of respondents who are strongly agree in the regard of had to wait long time before getting a bed in the ward those who are strongly agree are $8.182 \%$ disagree $3.636 \%$ neutral $20 \%$ agree $66.36 \%$ strongly agree $1.818 \%$.

\section{Table 9}

Bothered by noise at night from other patients

\begin{tabular}{|l|l|l|l|l|l|}
\hline & Frequency & Percent & Valid Percent & $\begin{array}{l}\text { Cumulative } \\
\text { Percent }\end{array}$ \\
\hline \multirow{4}{*}{ Strongly disagree } & 1 & .9 & .9 & .9 \\
Disagree & 13 & 11.8 & 11.8 & 12.7 \\
& Neutral & 47 & 42.7 & 42.7 & 55.5 \\
& Agree & 44 & 40.0 & 40.0 & 95.5 \\
strongly agree & 5 & 4.5 & 4.5 & 100.0 \\
Total & 110 & 100.0 & 100.0 & \\
\hline
\end{tabular}

Table 9: shows percentage of the respondents who are strongly disagree $0.909 \%$ those who are disagree $11.82 \%$ neutral $42.73 \%$ agree are $40 \%$ and strongly agree are $4.545 \%$. 
INTERNATIONAL JOURNAL OF ACADEMIC RESEARCH IN BUSINESS AND SOCIAL SCIENCES Vol. 9, No. 5, May, 2019, E-ISSN: 2222-6990 (C) 2019 HRMARS

\section{Table 10}

Bothered by noise at night from hospital staff

\begin{tabular}{|ll|l|l|l|l|}
\hline & Frequency & Percent & Valid Percent & $\begin{array}{l}\text { Cumulative } \\
\text { Percent }\end{array}$ \\
\hline \multirow{4}{*}{ Valid } & Strongly disagree & 3 & 2.7 & 2.7 & 2.7 \\
& Disagree & 12 & 10.9 & 10.9 & 13.6 \\
& Neutral & 43 & 39.1 & 39.1 & 52.7 \\
& Agree & 49 & 44.5 & 44.5 & 97.3 \\
& strongly agree & 3 & 2.7 & 2.7 & 100.0 \\
Total & 110 & 100.0 & 100.0 & \\
\hline
\end{tabular}

Table10: shows that the percentage of respondents who are strongly disagree are $2.727 \%$, disagree $10.91 \%$ neutral are $39.09 \%$ agree are 44.555 and strongly agree are 2

Table 11

Not satisfied with the cleanliness of hospital ward/room

\begin{tabular}{|c|l|l|l|l|l|}
\hline & Frequency & Percent & Valid Percent & $\begin{array}{l}\text { Cumulative } \\
\text { Percent }\end{array}$ \\
\hline \multirow{6}{*}{ Valid } & Strongly disagree & 1 & .9 & .9 & .9 \\
Disagree & 45 & 40.9 & 40.9 & 41.8 \\
& Neutral & 20 & 18.2 & 18.2 & 60.0 \\
& Agree & 43 & 39.1 & 39.1 & 99.1 \\
strongly agree & 1 & .9 & .9 & 100.0 \\
Total & 110 & 100.0 & 100.0 & \\
\hline
\end{tabular}

Table 1: shows percentage of the respondents who are not satisfied with the hospital cleanliness ward and rooms strongly disagree are $0.909 \%$ disagree are $40.91 \%$ neutral are $18.18 \%$ agree are $39.09 \%$ and strongly agree are 0.000

Table 12

Not satisfied with the cleanliness of hospital ward/room

\begin{tabular}{|ll|l|l|l|l|}
\hline & Frequency & Percent & Valid Percent & $\begin{array}{l}\text { Cumulative } \\
\text { Percent }\end{array}$ \\
\hline \multirow{4}{*}{ Valid } & Disagree & 40 & 36.4 & 36.4 & 36.4 \\
& Neutral & 30 & 27.3 & 27.3 & 63.6 \\
& Agree & 40 & 36.4 & 36.4 & 100.0 \\
& Total & 110 & 100.0 & 100.0 & \\
\hline
\end{tabular}


INTERNATIONAL JOURNAL OF ACADEMIC RESEARCH IN BUSINESS AND SOCIAL SCIENCES Vol. 9, No. 5, May, 2019, E-ISSN: 2222-6990 (C) 2019 HRMARS

Table 12: shows total percentage of the the respondents in the regard of not satisfied with cleanliness of hospital ward /rooms those who are disagree $36.36 \%$ those are neutral $27.27 \%$ those who are agree $36.36 \%$

\section{Table 13}

Not satisfied with hospital food

\begin{tabular}{|ll|l|l|l|l|}
\hline & & Frequency & Percent & Valid Percent & $\begin{array}{l}\text { Cumulative } \\
\text { Percent }\end{array}$ \\
\hline \multirow{4}{*}{ Valid } & Disagree & 21 & 19.1 & 19.1 & 19.1 \\
& Neutral & 45 & 40.9 & 40.9 & 60.0 \\
& Agree & 44 & 40.0 & 40.0 & 100.0 \\
& Total & 110 & 100.0 & 100.0 & \\
\hline
\end{tabular}

Table: 13 Respondents who are not satisfied with hospital food disagree are $19.09 \%$ neutral are $40.91 \%$ agree are $40 \%$.

\section{Table 14}

Did not get understandable answers from doctors in response to important questions

\begin{tabular}{|cl|l|l|l|l|}
\hline & Frequency & Percent & Valid Percent & $\begin{array}{l}\text { Cumulative } \\
\text { Percent }\end{array}$ \\
\hline \multirow{4}{*}{ Valid } & disagree & 6 & 5.5 & 5.5 & 5.5 \\
& Neutral & 42 & 38.2 & 38.2 & 43.6 \\
& Agree & 57 & 51.8 & 51.8 & 95.5 \\
& strongly agree & 5 & 4.5 & 4.5 & 100.0 \\
& Total & 110 & 100.0 & 100.0 & \\
\hline
\end{tabular}

Table:14 shows percentage of respondents who are strongly disagree are $5.455 \%$ neutral are $38.18 \%$ agree are $51.82 \%$ and strongly agree are $4.545 \%$

\section{Table 15}

Did not have relationship of confidence or trust with the doctors

\begin{tabular}{|ll|l|l|l|l|}
\hline & Frequency & Percent & Valid Percent & $\begin{array}{l}\text { Cumulative } \\
\text { Percent }\end{array}$ \\
\hline \multirow{4}{*}{ Valid } & disagree & 12 & 10.9 & 10.9 & 10.9 \\
& Neutral & 21 & 19.1 & 19.1 & 30.0 \\
& Agree & 75 & 68.2 & 68.2 & 98.2 \\
& strongly agree & 2 & 1.8 & 1.8 & 100.0 \\
Total & 110 & 100.0 & 100.0 & \\
\hline
\end{tabular}


INTERNATIONAL JOURNAL OF ACADEMIC RESEARCH IN BUSINESS AND SOCIAL SCIENCES Vol. 9, No. 5, May, 2019, E-ISSN: 2222-6990 (C) 2019 HRMARS

Table 15 shows the percentage of the respondents who are disagree are $10.91 \%$ neutral are $19.09 \%$ agree are $68.18 \%$ strongly agree are $1.818 \%$.

Table 16

Why I $\mathrm{m}$ important tests were being done not explained in a way patient could understand

\begin{tabular}{|c|l|l|l|l|l|}
\hline & Frequency & Percent & Valid Percent & $\begin{array}{l}\text { Cumulative } \\
\text { Percent }\end{array}$ \\
\hline \multirow{6}{*}{ Strongly disagree } & 1 & .9 & .9 & .9 \\
Dalid & 6 & 5.5 & 5.5 & 6.4 \\
& Neutral & 18 & 16.4 & 16.4 & 22.7 \\
& Agree & 78 & 70.9 & 70.9 & 93.6 \\
strongly agree & 7 & 6.4 & 6.4 & 100.0 \\
Total & 110 & 100.0 & 100.0 & \\
\hline
\end{tabular}

Table 16: shows that the respondents who are agree in the regard of why important test were being done not explained in a way patient could understand those who are strongly disagree are $0.000 \%$ those who are disagree are $5.455 \%$ those who are neutral $16.36 \%$ and those who are strongly agree are 6.364

Table 17

Important side effects of medications not explained in a way patient could understand

\begin{tabular}{|c|l|l|l|l|l|}
\hline & Frequency & Percent & Valid Percent & $\begin{array}{l}\text { Cumulative } \\
\text { Percent }\end{array}$ \\
\hline \multirow{6}{*}{ Valid } & 2 & 1.8 & 1.8 & 1.8 \\
& Disagree & 12 & 10.9 & 10.9 & 12.7 \\
Neutral & 11 & 10.0 & 10.0 & 22.7 \\
Agree & 76 & 69.1 & 69.1 & 91.8 \\
strongly agree & 9 & 8.2 & 8.2 & 100.0 \\
Total & 110 & 100.0 & 100.0 & \\
\hline
\end{tabular}

Table 17: shows the percentage of the respondents who are strongly disagree are $1.818 \%$ disagree are $10.91 \%$ neutral are 105 agree are $69.09 \%$ strongly agree $8.182 \%$. 
INTERNATIONAL JOURNAL OF ACADEMIC RESEARCH IN BUSINESS AND SOCIAL SCIENCES Vol. 9, No. 5, May, 2019, E-ISSN: 2222-6990 @ 2019 HRMARS

Table 18

Did not get understandable answers from nurses in response to important questions

\begin{tabular}{|c|l|l|l|l|l|}
\hline & Frequency & Percent & Valid Percent & $\begin{array}{l}\text { Cumulative } \\
\text { Percent }\end{array}$ \\
\hline \multirow{6}{*}{ Valid } & Strongly disagree & 1 & .9 & .9 & .9 \\
& Disagree & 10 & 9.1 & 9.1 & 10.0 \\
& Neutral & 11 & 10.0 & 10.0 & 20.0 \\
& Agree & 79 & 71.8 & 71.8 & 91.8 \\
Strongly agree & 9 & 8.2 & 8.2 & 100.0 \\
Total & 110 & 100.0 & 100.0 & \\
\hline
\end{tabular}

Table18: shows percentage of respondents who are strongly disagree are $0.000 \%$ disagree are $9.091 \%$ neutral are $10 \%$ agree are $71.82 \%$ and strongly agree are $8.182 \%$.

Table 19

Did not have relationship of confidence or trust with the nurses

\begin{tabular}{|c|l|l|l|l|l|}
\hline & Frequency & Percent & Valid Percent & $\begin{array}{l}\text { Cumulative } \\
\text { Percent }\end{array}$ \\
\hline \multirow{6}{*}{ Valid } & Strongly disagree & 6 & 5.5 & 5.5 & 5.5 \\
& Disagree & 4 & 3.6 & 3.6 & 9.1 \\
& Neutral & 4 & 3.6 & 3.6 & 12.7 \\
& Agree & 86 & 78.2 & 78.2 & 90.9 \\
strongly agree & 10 & 9.1 & 9.1 & 100.0 \\
Total & 110 & 100.0 & 100.0 & \\
\hline
\end{tabular}

Table 19: shows percentage of respondents who are strongly disagree are $5.455 \%$ disagree are $3.636 \%$ neutral are $3.636 \%$ agree are $78.18 \%$ and strongly agree are 9.09

Table 20

There were not enough nurses on duty to care for the patient

\begin{tabular}{|c|c|c|c|c|c|}
\hline & & Frequency & Percent & Valid Percent & $\begin{array}{l}\text { Cumulative } \\
\text { Percent }\end{array}$ \\
\hline \multirow{6}{*}{ Valid } & Strongly disagree & 7 & 6.4 & 6.4 & 6.4 \\
\hline & Disagree & 6 & 5.5 & 5.5 & 11.8 \\
\hline & Neutral & 21 & 19.1 & 19.1 & 30.9 \\
\hline & Agree & 71 & 64.5 & 64.5 & 95.5 \\
\hline & strongly agree & 5 & 4.5 & 4.5 & 100.0 \\
\hline & Total & 110 & 100.0 & 100.0 & \\
\hline
\end{tabular}


INTERNATIONAL JOURNAL OF ACADEMIC RESEARCH IN BUSINESS AND SOCIAL SCIENCES Vol. 9, No. 5, May, 2019, E-ISSN: 2222-6990 (C) 2019 HRMARS

Table20: shows percentage of the students that are strongly disagree is $6.364 \%$ disagree are 5.4555 neutral are $19.09 \%$ agree are 64.555 and strongly agree are $4.545 \%$.

Table: 21

On average, waited for help for more than $\mathbf{5}$ minutes after pressing call bell

\begin{tabular}{|ll|l|l|l|l|}
\hline & Frequency & Percent & Valid Percent & $\begin{array}{l}\text { Cumulative } \\
\text { Percent }\end{array}$ \\
\hline \multirow{4}{*}{ Valid } & Strongly disagree & 1 & .9 & .9 & .9 \\
& Disagree & 20 & 18.2 & 18.2 & 19.1 \\
& Neutral & 20 & 18.2 & 18.2 & 37.3 \\
& Agree & 65 & 59.1 & 59.1 & 96.4 \\
Strongly agree & 4 & 3.6 & 3.6 & 100.0 \\
Total & 110 & 100.0 & 100.0 & \\
\hline
\end{tabular}

Table: 21 shows percentage of the respondents who are strongly disagree is $0.000 \%$ disagree is $18.18 \%$ neutral is $18.18 \%$ agree is $59.09 \%$ strongly agree are $3.636 \%$.

Table: 22

Patient received conflicting information from members of the medical team

\begin{tabular}{|c|c|c|c|c|c|}
\hline & & $\begin{array}{l}\text { Frequenc } \\
\text { y }\end{array}$ & Percent & $\begin{array}{l}\text { Valid } \\
\text { Percent }\end{array}$ & $\begin{array}{l}\text { Cumulative } \\
\text { Percent }\end{array}$ \\
\hline \multirow{6}{*}{ Valid } & disagree & 19 & 17.3 & 17.3 & 17.3 \\
\hline & Neutral & 7 & 6.4 & 6.4 & 23.6 \\
\hline & Agree & 75 & 68.2 & 68.2 & 91.8 \\
\hline & strongly & 9 & 8.2 & 8.2 & 100.0 \\
\hline & agree & & & & \\
\hline & Total & 110 & 100.0 & 100.0 & \\
\hline
\end{tabular}

Table: 22 shows the percentage of respondents who are disagree $17.27 \%$ neutral $6.364 \%$ agree $68.18 \%$ strongly agree is $8.182 \%$. 
INTERNATIONAL JOURNAL OF ACADEMIC RESEARCH IN BUSINESS AND SOCIAL SCIENCES Vol. 9, No. 5, May, 2019, E-ISSN: 2222-6990 (C) 2019 HRMARS

Table: 23

Not given enough information about condition and treatment

\begin{tabular}{|cl|l|l|l|l|}
\hline & Frequency & Percent & Valid Percent & $\begin{array}{l}\text { Cumulative } \\
\text { Percent }\end{array}$ \\
\hline \multirow{6}{*}{ Strongly disagree } & 5 & 4.5 & 4.5 & 4.5 \\
Valid & 15 & 13.6 & 13.6 & 18.2 \\
& Neutral & 7 & 6.4 & 6.4 & 24.5 \\
& Agree & 66 & 60.0 & 60.0 & 84.5 \\
strongly agree & 17 & 15.5 & 15.5 & 100.0 \\
Total & 110 & 100.0 & 100.0 & \\
\hline
\end{tabular}

Table 23 shows that the total number of the respondents who are strongly disagree are $4.545 \%$ who are disagree $13.64^{\wedge}$ neutral are $6.364 \%$ agree are $60 \%$ and strongly agre are 15.4

Table: 24

Not involved in decisions about care and treatment as much as the patient wanted

\begin{tabular}{|ll|l|l|l|l|}
\hline & Frequency & Percent & Valid Percent & $\begin{array}{l}\text { Cumulative } \\
\text { Percent }\end{array}$ \\
\hline \multirow{4}{*}{ Valid } & disagree & 11 & 10.0 & 10.0 & 10.0 \\
& Neutral & 7 & 6.4 & 6.4 & 16.4 \\
& Agree & 77 & 70.0 & 70.0 & 86.4 \\
& strongly agree & 15 & 13.6 & 13.6 & 100.0 \\
Total & 110 & 100.0 & 100.0 & \\
\hline
\end{tabular}

Table 24: shows the percentage of respondents who are disagree $10 \%$ neutral $6.364 \%$ agree $70 \%$ and strongly agree $13.64 \%$.

Table: 25

Family not given enough opportunity to talk to the doctor if they wanted to

\begin{tabular}{|ll|l|l|l|l|}
\hline & Frequency & Percent & Valid Percent & $\begin{array}{l}\text { Cumulative } \\
\text { Percent }\end{array}$ \\
\hline \multirow{4}{*}{ Valid } & disagree & 7 & 6.4 & 6.4 & 6.4 \\
& Neutral & 1 & .9 & .9 & 7.3 \\
& Agree & 90 & 81.8 & 81.8 & 89.1 \\
& strongly agree & 12 & 10.9 & 10.9 & 100.0 \\
& Total & 110 & 100.0 & 100.0 & \\
\hline
\end{tabular}


INTERNATIONAL JOURNAL OF ACADEMIC RESEARCH IN BUSINESS AND SOCIAL SCIENCES Vol. 9, No. 5, May, 2019, E-ISSN: 2222-6990 (C) 2019 HRMARS

Table: 25 shows percentage age of the respondents who are disagree $6.364 \%$ neutral are $0.000 \%$ agree are $81.82 \%$ and strongly agree is $10.91 \%$.

Table: 26

Did not find anyone on staff to talk to about worries and fears

\begin{tabular}{|ll|l|l|l|l|}
\hline & Frequency & Percent & Valid Percent & $\begin{array}{l}\text { Cumulative } \\
\text { Percent }\end{array}$ \\
\hline \multirow{4}{*}{ Valid } & disagree & 6 & 5.5 & 5.5 & 5.5 \\
& Neutral & 3 & 2.7 & 2.7 & 8.2 \\
& Agree & 88 & 80.0 & 80.0 & 88.2 \\
& strongly agree & 13 & 11.8 & 11.8 & 100.0 \\
Total & 110 & 100.0 & 100.0 & \\
\hline
\end{tabular}

Table26: shows percentage of respondent in the regard of they did not find anyone on staff to talk to about worried and fears disagree are $5.455 \%$ neutral is $2.727 \%$ agree $80 \%$ and strongly agree is $11.82 \%$.

Table: 27

Not given enough privacy during discussion about condition and treatment

\begin{tabular}{|cl|l|l|l|l|}
\hline & Frequency & Percent & Valid Percent & $\begin{array}{l}\text { Cumulative } \\
\text { Percent }\end{array}$ \\
\hline \multirow{4}{*}{ Valid } & Disagree & 1 & .9 & .9 & .9 \\
& Neutral & 7 & 6.4 & 6.4 & 7.3 \\
& Agree & 98 & 89.1 & 89.1 & 96.4 \\
& strongly agree & 4 & 3.6 & 3.6 & 100.0 \\
& Total & 110 & 100.0 & 100.0 & \\
\hline
\end{tabular}

Table 27 shows the percentage of the respondents those who are disagree are $0.909 \%$ those who are neutral $6.364 \%$ those who are agree $89.09 \%$ those who are strongly agree $3.636 \%$. 
INTERNATIONAL JOURNAL OF ACADEMIC RESEARCH IN BUSINESS AND SOCIAL SCIENCES Vol. 9, No. 5, May, 2019, E-ISSN: 2222-6990 (C) 2019 HRMARS

Table: 28

Not given enough privacy during examination or treatment

\begin{tabular}{|ll|l|l|l|l|}
\hline & Frequency & Percent & Valid Percent & $\begin{array}{l}\text { Cumulative } \\
\text { Percent }\end{array}$ \\
\hline \multirow{4}{*}{ Valid } & Neutral & 6 & 5.5 & 5.5 & 5.5 \\
& Agree & 101 & 91.8 & 91.8 & 97.3 \\
& strongly agree & 3 & 2.7 & 2.7 & 100.0 \\
& Total & 110 & 100.0 & 100.0 & \\
\hline
\end{tabular}

Table 28 shows that the percentage of the respondents neutral $5.455 \%$ agree are $91.82 \%$ strongly agree are $2.727 \%$

Table: 29

Beforehand didn't get understandable answers to questions about the operation/procedure

\begin{tabular}{|ll|l|l|l|l|}
\hline & Frequency & Percent & Valid Percent & $\begin{array}{l}\text { Cumulative } \\
\text { Percent }\end{array}$ \\
\hline \multirow{4}{*}{ Valid } & disagree & 6 & 5.5 & 5.5 & 5.5 \\
& Neutral & 1 & .9 & .9 & 6.4 \\
& Agree & 103 & 93.6 & 93.6 & 100.0 \\
& Total & 110 & 100.0 & 100.0 & \\
\hline
\end{tabular}

Table: 30

Risks/benefits of operations/procedures not explained in a way patient could understand

\begin{tabular}{|ll|l|l|l|l|}
\hline & & Frequency & Percent & Valid Percent & $\begin{array}{l}\text { Cumulative } \\
\text { Percent }\end{array}$ \\
\hline \multirow{4}{*}{ Valid } & Neutral & 5 & 4.5 & 4.5 & 4.5 \\
& Agree & 105 & 95.5 & 95.5 & 100.0 \\
& Total & 110 & 100.0 & 100.0 & \\
\hline
\end{tabular}

Table29: shows percentage of respondents who are neutral 4.5455 and agree are $95.45 \%$. 
INTERNATIONAL JOURNAL OF ACADEMIC RESEARCH IN BUSINESS AND SOCIAL SCIENCES Vol. 9, No. 5, May, 2019, E-ISSN: 2222-6990 (C) 2019 HRMARS

Table: 31

Process of anesthesia/pain control not explained in a way patient could understand

\begin{tabular}{|ll|l|l|l|l|}
\hline & Frequency & Percent & Valid Percent & $\begin{array}{l}\text { Cumulative } \\
\text { Percent }\end{array}$ \\
\hline \multirow{4}{*}{ Valid } & disagree & 6 & 5.5 & 5.5 & 5.5 \\
& Neutral & 2 & 1.8 & 1.8 & 7.3 \\
& Agree & 100 & 90.9 & 90.9 & 98.2 \\
& strongly agree & 2 & 1.8 & 1.8 & 100.0 \\
& Total & 110 & 100.0 & 100.0 & \\
\hline
\end{tabular}

Table 31 shows percentage of the respondents who are disagree are $5.455 \%$ neutral $1.818 \%$ those who are agree are $90.91 \%$ and those who are strongly agree $1.818 \%$

Table: 32

Not given understandable explanation about how the operation/procedure had gone

\begin{tabular}{|ll|l|l|l|l|}
\hline & Frequency & Percent & Valid Percent & $\begin{array}{l}\text { Cumulative } \\
\text { Percent }\end{array}$ \\
\hline \multirow{4}{*}{ Valid } & disagree & 1 & .9 & .9 & .9 \\
& Agree & 108 & 98.2 & 98.2 & 99.1 \\
& strongly agree & 1 & .9 & .9 & 100.0 \\
& Total & 110 & 100.0 & 100.0 & \\
\hline
\end{tabular}

Figure 32

Table 32 shows percentage of the respondents who are disagree are $0.909 \%$ who are agree $98.18 \%$ who are strongly agree 0.900

Table: 33

Tests not carried out at their scheduled time

\begin{tabular}{|ll|l|l|l|l|}
\hline & & Frequency & Percent & Valid Percent & $\begin{array}{l}\text { Cumulative } \\
\text { Percent }\end{array}$ \\
\hline \multirow{4}{*}{ Valid } & disagree & 1 & .9 & .9 & .9 \\
& Neutral & 7 & 6.4 & 6.4 & 7.3 \\
& Agree & 102 & 92.7 & 92.7 & 100.0 \\
& Total & 110 & 100.0 & 100.0 & \\
\hline
\end{tabular}


INTERNATIONAL JOURNAL OF ACADEMIC RESEARCH IN BUSINESS AND SOCIAL SCIENCES Vol. 9, No. 5, May, 2019, E-ISSN: 2222-6990 (C) 2019 HRMARS

Table 33 shows percentage of respondents who are disagree are $0.000 \%$ who are neutral $6.364 \%$ who are agree $92.73 \%$.

Table: 34

Not treated with respect and dignity during the hospital admission

\begin{tabular}{|ll|l|l|l|l|}
\hline & Frequency & Percent & Valid Percent & $\begin{array}{l}\text { Cumulative } \\
\text { Percent }\end{array}$ \\
\hline \multirow{4}{*}{ Valid } & disagree & 3 & 2.7 & 2.7 & 2.7 \\
& Neutral & 11 & 10.0 & 10.0 & 12.7 \\
& Agree & 93 & 84.5 & 84.5 & 97.3 \\
strongly agree & 3 & 2.7 & 2.7 & 100.0 \\
Total & 110 & 100.0 & 100.0 & \\
\hline
\end{tabular}

Table 34 shows the percentage of respondents who are disagree are $2.727 \%$ those who are neutral 105 those who are agree $84.55 \%$ those who are strongly agree 2.727 .

Table: 35

Doctors and nurses did not work very well together

\begin{tabular}{|ll|l|l|l|l|}
\hline & Frequency & Percent & Valid Percent & $\begin{array}{l}\text { Cumulative } \\
\text { Percent }\end{array}$ \\
\hline \multirow{4}{*}{ Vtrongly disagree } & 1 & .9 & .9 & .9 \\
Disagree & 1 & .9 & .9 & 1.8 \\
& Neutral & 6 & 5.5 & 5.5 & 7.3 \\
& Agree & 101 & 91.8 & 91.8 & 99.1 \\
Strongly agree & 1 & .9 & .9 & 100.0 \\
Total & 110 & 100.0 & 100.0 & \\
\hline
\end{tabular}

Table 35 shows percentage of respondents who are strongly disagree are $0.000 \%$ who are disagree $0.000 \%$ neutral 5.4555 agree $91.82 \%$ and strongly agree $0.000 \%$. 
INTERNATIONAL JOURNAL OF ACADEMIC RESEARCH IN BUSINESS AND SOCIAL SCIENCES Vol. 9, No. 5, May, 2019, E-ISSN: 2222-6990 (C) 2019 HRMARS

Table: 36

Never asked for views on the quality of care provided

\begin{tabular}{|c|l|l|l|l|l|}
\hline & Frequency & Percent & Valid Percent & $\begin{array}{l}\text { Cumulative } \\
\text { Percent }\end{array}$ \\
\hline \multirow{4}{*}{ Valid } & Strongly disagree & 1 & .9 & .9 & .9 \\
& Disagree & 2 & 1.8 & 1.8 & 2.7 \\
& Neutral & 3 & 2.7 & 2.7 & 5.5 \\
& Agree & 100 & 90.9 & 90.9 & 96.4 \\
strongly agree & 4 & 3.6 & 3.6 & 100.0 \\
Total & 110 & 100.0 & 100.0 & \\
\hline
\end{tabular}

Table shows percentage of respondents who are strongly disagree $0.000 \%$ disagree $1.818 \%$ agree $90.91 \%$ strongly agree $3.636 \%$.

Table 37

Thought he/she was not being charged fairly for their care and treatment

\begin{tabular}{|cl|l|l|l|l|}
\hline & Frequency & Percent & Valid Percent & $\begin{array}{l}\text { Cumulative } \\
\text { Percent }\end{array}$ \\
\hline \multirow{6}{*}{ Valid } & Strongly disagree & 1 & .9 & .9 & .9 \\
& Disagree & 15 & 13.6 & 13.6 & 14.5 \\
& Neutral & 9 & 8.2 & 8.2 & 22.7 \\
& Agree & 84 & 76.4 & 76.4 & 99.1 \\
strongly agree & 1 & .9 & .9 & 100.0 \\
Total & 110 & 100.0 & 100.0 & \\
\hline
\end{tabular}

Table 37 shows percentage of respondents who are strongly disagree $0.909 \%$ who are disagree $13.64 \%$ those who are neutral $8.182 \%$ and those who are AGREE 76.36\% AND THOSE WHO STRONGLY AGREE 0.909\%.

Table

Not knowing how much would eventually be paid worried the patient.

\begin{tabular}{|cl|l|l|l|l|}
\hline & Frequency & Percent & Valid Percent & $\begin{array}{l}\text { Cumulative } \\
\text { Percent }\end{array}$ \\
\hline \multirow{4}{*}{ Valid } & disagree & 25 & 22.7 & 22.7 & 22.7 \\
& Neutral & 19 & 17.3 & 17.3 & 40.0 \\
& Agree & 64 & 58.2 & 58.2 & 98.2 \\
& strongly agree & 2 & 1.8 & 1.8 & 100.0 \\
& Total & 110 & 100.0 & 100.0 & \\
\hline
\end{tabular}


INTERNATIONAL JOURNAL OF ACADEMIC RESEARCH IN BUSINESS AND SOCIAL SCIENCES

Vol. 9, No. 5, May, 2019, E-ISSN: 2222-6990 (C) 2019 HRMARS

Table: 38 shows the percentage of respondents who are disagree are $22.73 \%$ who are neutral 17.275 who are agree $58.18 \%$ and those who are strongly agree $1.181 \%$.

\section{Reliability:"}

Table 39

\section{Case Processing Summary}

\begin{tabular}{|ll|l|l|}
\hline & & $\mathrm{N}$ & $\%$ \\
\hline \multirow{4}{*}{ Cases } & Valid & 110 & 100.0 \\
& Excluded & 0 & .0 \\
& Total & 110 & 100.0 \\
\hline
\end{tabular}

a. Listwise deletion based on all variables in the procedure.

\section{Reliability Statistics}

\begin{tabular}{|l|l|}
\hline $\begin{array}{l}\text { Cronbach's } \\
\text { Alpha }\end{array}$ & N of Items \\
\hline .741 & 35 \\
\hline
\end{tabular}

Table shows that the value of Cronbach's alpha is greater than $0.7 \%$ thus the result meets the standard requirement of reliability of variable is standard variable.

\section{Validity:}

Table 40

KMO and Bartlett's Test

\begin{tabular}{|c|c|c|}
\hline & $\begin{array}{l}.458 \\
.528\end{array}$ \\
\hline \multicolumn{2}{|c|}{$\begin{array}{l}\text { Kaiser-Meyer-Olkin Measure of Sampling Adequacy. } \\
\text { Approx. Chi-Square }\end{array}$} & \\
\hline \multirow[t]{2}{*}{ Bartlett's Test of Sphericity } & Df & 741 \\
\hline & Sig. & .000 \\
\hline
\end{tabular}

Table shows that the instrument consist on variables it shows that KMO value is above .50 and Bartlett test is significant $p$ value is less than 0.05 so that the whole criteria fulfilled and the study is valid.

\section{Discussion}

Study revealed that patient satisfaction is an important factor for the positives of their opinion regarding hospital admission but, while talking about the admission in a tertiary care hospital this component requires attention. As Pakistan is a developing country there are existences of many factors that effect on this satisfaction as well as patient's opinions regarding hospital admission these 
are low income, over population, illiteracy, cultural differences. Health care system in the Pakistan is on the journey of progress and the standard of tertiary hospitals are still not satisfactory all these effects patient satisfaction that lead to the positive and negative direction of their opinions. But as different people have different level of thinking and perceiving so their opinion regarding hospital admission in tertiary care hospitals are differ it can be justifying by saying that level of thinking also affects all these. as now these days patients become more aware and concerning related to their health their demands also touch the heights that lead to the high level of expectations in a territory care hospital health facilities are not readily available that put the pressure on the patient satisfaction. Satisfaction can be used as tool for measuring the standard of health care system as well as quality of care. Patient's satisfaction from the bases of policy making strategies.

\section{Conclusion}

Patient satisfaction is one of the prominent indicators that present the level and standard of quality of care to the patient. Privacy should be provided to the patients during their treatment in the hospital and Doctors and nurses should communicate with the patient in effective way. Psychological support should provide to the patient by the health care provider so that patient can share their panic situation with the staff.

\section{Limitation}

These are some limitations that came in front while interpreting the findings. Short population size that cause limitation in data collection. Cultural and traditional difference cause hindrance in data collection from female patients. Time and cost consumption. Difficulty in measuring test.

\section{References}

Agarwal, D. (2006). Health sector reforms: Relevance in India. Indian Journal of Community Medicine, 31(4), 220.

Ahmad, M., Zafar, A., Griffin, S., Ahmad, S., Orakzai, N., \& Fayyaz, F. (2005). AN AUDIT OF PATIENTS'SATISFACTION AFTER ADULT DAY-CASE SURGERY AT AYUB TEACHING HOSPITAL, ABBOTTABAD. Journal of Ayub Medical College Abbottabad, 17(1).

Alam, M. Z., Aman, R., \& Hafizullah, M. (2011). Patient awareness survey in a tertiary care hospital. Journal of Postgraduate Medical Institute (Peshawar-Pakistan), 22(4).

Modebe, A. I., Azuike, E. C., Ucheagwa, C. M., Azuike, E. D., Obi, D. C., Epundu, U. U., ... \& Aniagboso, C. C. (2014). Patient satisfaction on admission in Nnamdi Azikiwe university teaching hospital, Nnewi, Nigeria. Science, 2(6), 596-600.

Boyer, L., Francois, P., Doutre, E., Weil, G., \& Labarere, J. (2006). Perception and use of the results of patient satisfaction surveys by care providers in a French teaching hospital. International Journal for quality in health care, 18(5), 359-364.

Delbanco, T. L. (1996). Quality of care through the patient's eyes.

Jenkinson, C., Coulter, A., Bruster, S., Richards, N., \& Chandola, T. (2002). Patients' experiences and satisfaction with health care: results of a questionnaire study of specific aspects of care. Qual Saf Health Care, 11(4), 335-339. 
Jenkinson, C., Coulter, A., Bruster, S., Richards, N., \& Chandola, T. (2002). Patients' experiences and satisfaction with health care: results of a questionnaire study of specific aspects of care. Qual Saf Health Care, 11(4), 335-339.

Pakistan Economics Survey. Population Labor Force and Employment, Education , Economic Advisers Wing, Finance Division, Government of Pakistan ,Islamabad;2011-12.p.8-10.

Qidwai, W., Ali, S. S., Baqi, M., \& Ayub, S. (2005). Patient expectations from an emergency medical service. Journal of Ayub Medical College, 17(3), 3.

Singh, J. (1989). The patient satisfaction concept: a review and reconceptualization. ACR North American Advances.

Wensing, M., \& Elwyn, G. (2003). Methods for incorporating patients' views in health care. Bmj, 326(7394), 877-879. 